\title{
Exploring the Ni redox activity in polyanionic compounds as conceivable high potential cathodes for Na rechargeable batteries
}

\author{
Huang Zhang ${ }^{1,2}$, Ivana Hasa ${ }^{1,2}$, Daniel Buchholz ${ }^{1,2}$, Bingsheng Qin ${ }^{1,2}$, Dorin Geiger ${ }^{3}$, Sangsik Jeong ${ }^{1,2}$, \\ Ute Kaiser $^{3}$ and Stefano Passerini ${ }^{1,2}$
}

\begin{abstract}
Although nickel-based polyanionic compounds are expected to exhibit a high operating voltage for batteries based on the $\mathrm{Ni}^{2+/ 3+}$ redox couple activity, some rare experimental studies on the electrochemical performance of these materials are reported, resulting from the poor kinetics of the bulk materials in both $\mathrm{Li}$ and $\mathrm{Na}$ nonaqueous systems. Herein, the electrochemical activity of the $\mathrm{Ni}^{2+/ 3+}$ redox couple in the mixed-polyanionic framework $\mathrm{Na}_{4} \mathrm{Ni}_{3}\left(\mathrm{PO}_{4}\right)_{2}\left(\mathrm{P}_{2} \mathrm{O}_{7}\right)$ is reported for the first time. This novel material exhibits a remarkably high operating voltage when cycled in sodium cells in both carbonate- and ionic liquid-based electrolytes. The application of a carbon coating and the use of an ionic liquid-based electrolyte enable the reversible sodium ion (de-)insertion in the host structure accompanied by the redox activity of $\mathrm{Ni}^{2+/ 3+}$ at operating voltages as high as $4.8 \mathrm{~V}$ vs Na/Na+. These results present the realization of Ni-based mixed polyanionic compounds with improved electrochemical activity and pave the way for the discovery of new Na-based high potential cathode materials.

NPG Asia Materials (2017) 9, e370; doi:10.1038/am.2017.41; published online 31 March 2017
\end{abstract}

\section{INTRODUCTION}

Lithium-ion batteries have been largely recognized as the most efficient electrochemical energy storage devices for both portable electronics and electric vehicle applications. ${ }^{1,2}$ However, the growth and diversification of the energy storage market trigger interest in low-cost and environmentally friendly alternative systems. In addition, recent concerns over the cost and future availability of lithium highlight the urgent need to exploit alternative energy storage systems. ${ }^{3}$ In these terms, sodium ( $\mathrm{Na}$ )-ion batteries are attractive candidates because of the electrochemistry that is similar to the well-established lithium-ion technology. ${ }^{4}$ To date, the $\mathrm{LiFePO}_{4}$ olivine with $\left(\mathrm{PO}_{4}\right)^{3-}$ polyanionic framework, owing to its superior thermal stability and low cost, is considered to be one of the best electrode materials for lithium-ion batteries, mostly in view of its stable operating voltage and satisfactory specific capacity. However, the intrinsic tunability of the operating voltage of polyanionic compounds because of the presence of different transition metals such as $\mathrm{Mn}, \mathrm{Co}$ and $\mathrm{Ni}^{5-7}$ has triggered interest in alternative frameworks exhibiting higher cell voltages. According to theoretical prediction, lithium nickel phosphate has a remarkably high working potential $\left(\sim 5.1{\left.\mathrm{~V} v \mathrm{Li}^{+} / \mathrm{Li}\right)}^{\circ}\right.$ because of the $\mathrm{Ni}^{2+/ 3+}$ redox activity. ${ }^{8}$ Unfortunately, several studies have demonstrated that the implementation of this material is restricted by several drawbacks such as the intrinsic sluggish kinetics attributable to the low electronic conductivity, the poor lithium transport in commonly used electrolyte systems and the structural instability of the delithiated phases upon cycling that require further studies to obtain high-performance Ni-based phosphates as high voltage cathodes for battery application. ${ }^{8-12}$

With regard to Na-based systems, considerable research has also been devoted to NASICON (sodium (Na) Super Ionic CONductor)type polyanionic materials, such as $\mathrm{NaMPO}_{4},{ }^{13,14} \mathrm{Na}_{2} \mathrm{MP}_{2} \mathrm{O}_{7}$ (where $\mathrm{M}$ is a transition metal $)^{15,16}$ and $\mathrm{Na}_{3} \mathrm{~V}_{2}\left(\mathrm{PO}_{4}\right)_{3},{ }^{17,18}$ as cathode materials for room temperature Na-ion batteries. However, the low energy densities resulting from the low theoretical capacity and, generally, cell voltage, as well as the poor rate capability compared with their lithium counterparts, have inhibited the widespread development of Na-ion batteries. ${ }^{19}$ Unlike $\mathrm{LiMPO}_{4}$, the $\mathrm{NaMPO}_{4}$ thermodynamically stable phase obtained under the conventional synthesis conditions is the maricite phase that is known to be electrochemically inactive with respect to the olivine phase..$^{20,21}$ Among the polyanionic frameworks, pyrophosphate compounds offer a stable three-dimensional $\left(\mathrm{P}_{2} \mathrm{O}_{7}\right)^{4-}$ framework with multiple sites for $\mathrm{Na}$ ions. Fe-based pyrophosphates have been reported to exhibit enhanced rate capability performance most likely because of the presence of open diffusion pathways for $\mathrm{Na}$ ions. Indeed, first principle calculations confirmed a relatively low migration barrier for diffusion of $\mathrm{Na}$ ions. ${ }^{15}$

In this context, a new polyanionic compound of the general formula $\mathrm{Na}_{4} \mathrm{M}_{3}\left(\mathrm{PO}_{4}\right)_{2}\left(\mathrm{P}_{2} \mathrm{O}_{7}\right)$ with the $\mathrm{Fe}^{2+/ 3+}$ redox couple has been proposed by Kang and colleagues ${ }^{22,23}$ as a promising cathode in terms

${ }^{1}$ Helmholtz Institute UIm, UIm, Germany; ${ }^{2}$ Karlsruhe Institute of Technology (KIT), Karlsruhe, Germany and ${ }^{3}$ Central Facility of Electron Microscopy, Electron Microscopy Group of Materials Science, University of Ulm, Ulm, Germany

Correspondence: Professor S Passerini, Helmholtz Institute UIm, Karlsruhe Institute of Technology, Helmholtzstrasse 11, 89081 Ulm, Germany.

E-mail: stefano.passerini@kit.edu

Received 23 October 2016; revised 20 January 2017; accepted 25 January 2017 
of its superior Na mobility and thermal stability. The material has a theoretical capacity of $129 \mathrm{mAh} \mathrm{g}^{-1}$ and an operating potential of $\sim 3.2 \mathrm{~V}$ vs $\mathrm{Na}^{+} / \mathrm{Na}$, higher than the potential exhibited by $\mathrm{NaFePO}_{4}$ and $\mathrm{Na}_{2} \mathrm{FeP}_{2} \mathrm{O}_{7} \cdot{ }^{13,24}$ According to first principle calculations, the $\mathrm{P}_{2} \mathrm{O}_{7}$ dimers can buffer the volume change during cycling $(<4 \%)$ and offer $\mathrm{Na}$ diffusion pathways in the three-dimensional open framework that may ensure long-term cycling performance. Cobalt-based polyanionic compounds show electrochemical properties similar to the Ni-based analogs in $\mathrm{Li}$ systems with low conductivity and poor thermal stability. ${ }^{25,26}$ However, the $\mathrm{Na}_{4} \mathrm{Co}_{3}\left(\mathrm{PO}_{4}\right)_{2}\left(\mathrm{P}_{2} \mathrm{O}_{7}\right)$ synthesized by a sol-gel method shows an average working potential of $\sim 4.4 \mathrm{~V}$ vs $\mathrm{Na}^{+} / \mathrm{Na}$ and a high rate capability for $\mathrm{Na}$ ions. ${ }^{27} \mathrm{~A}$ combination of different polyanionic groups could contribute to outstanding ion diffusion and voltage profile in $\mathrm{Na}$-ion batteries as well as structure stability during the $\mathrm{Na}$ (de-)insertion process. Interestingly, a theoretical prediction reported by Islam and colleagues ${ }^{28}$ has pointed out that doping the $\mathrm{Na}_{4} \mathrm{Fe}_{3}\left(\mathrm{PO}_{4}\right)_{2}\left(\mathrm{P}_{2} \mathrm{O}_{7}\right)$ with $\mathrm{Ni}$ can lead to a significant increase in the cell voltage.

In light of such results, we report the investigation of a Ni-based polyanionic material as a potential high voltage cathode for rechargeable $\mathrm{Na}$ batteries. In this work, the pristine and carbon-coated materials, that is, $\mathrm{Na}_{4} \mathrm{Ni}_{3}\left(\mathrm{PO}_{4}\right)_{2}\left(\mathrm{P}_{2} \mathrm{O}_{7}\right)$ and $\mathrm{Na}_{4} \mathrm{Ni}_{3}\left(\mathrm{PO}_{4}\right)_{2}\left(\mathrm{P}_{2} \mathrm{O}_{7}\right) / \mathrm{C}$, were stoichiometrically prepared by a conventional solid-state method. This study represents an intriguing investigation in terms of both structural and electrochemical characterization of the Ni redox activity in mixed polyanionic compounds. The electrochemical activity of the $\mathrm{Ni}^{2+/ 3+}$ redox couple in $\mathrm{Na}$ cells, predicted by previous theoretical calculations, is experimentally reported in this paper for the first time. The attractive possibility of using high operating voltage Na-based cathode materials highlights the need of electrolyte media with a wide electrochemical stability window, opening a new unexplored research field for Na-ion batteries.

\section{MATERIALS AND METHODS}

\section{Synthesis of materials}

All chemicals were used as received without further purification. Syntheses were carried out by simple and time-efficient solid-state reactions. For the precursor preparation, sodium pyrophosphate decahydrate $\left(\mathrm{Na}_{4} \mathrm{P}_{2} \mathrm{O}_{7} \cdot 10 \mathrm{H}_{2} \mathrm{O}, \geqslant 99 \%\right.$, Alfa Aesar, Karlsruhe, Germany), nickel (II) acetate tetrahydrate (Ni $\left(\mathrm{OCOCH}_{3}\right)_{2} \cdot 4 \mathrm{H}_{2} \mathrm{O}, \geqslant 98 \%$, Alfa Aesar) and ammonium dihydrogen phosphate $\left(\mathrm{NH}_{4} \mathrm{H}_{2} \mathrm{PO}_{4}, \geqslant 99 \%\right.$, Merck Millipore, Darmstadt, Germany) were mixed by ball-milling in acetone according to stoichiometric proportions. Citric acid monohydrate $\left(\mathrm{C}_{6} \mathrm{H}_{8} \mathrm{O}_{7} \cdot \mathrm{H}_{2} \mathrm{O}, \geqslant 99 \%\right.$, Alfa Aesar) was used as a carbon source for the carbon-coated sample. After intensive milling, the mixture was dried at room temperature and ground. The precursor powder obtained was preheated at $300^{\circ}$ $\mathrm{C}$ for $6 \mathrm{~h}$ and then annealed at $500{ }^{\circ} \mathrm{C}$ (heating rate: $2{ }^{\circ} \mathrm{C} \mathrm{min}-1$ ) for $10 \mathrm{~h}$ in an aluminum oxide crucible using a tubular furnace under steady argon flow. Cooling to room temperature and grinding followed. The carbon-coated material was synthesized under the same conditions using citric acid monohydrate as the organic carbon source in the precursor preparation. A schematic representation of the synthesis procedure is reported in Supplementary Figure S1.

\section{Material characterization}

$\mathrm{X}$-ray diffraction (XRD) analysis was performed in Bragg-Brentano geometry using a Bruker D8 Advance diffractometer (Bruker, Karlsruhe, Germany). All diffractograms were recorded with $\mathrm{CuK}_{\alpha}$ radiation $(\lambda=0.154 \mathrm{~nm})$ in the $2 \theta$ range of $10^{\circ}-90^{\circ}$ with a step size of $0.01^{\circ}$. The structures were refined using the Rietveld method with the DIFFRAC PLUS TOPAS 4.2 software (Bruker). Morphological and structural characterizations were conducted via ZEISS 1550VP Field Emission scanning electron microscopy (Carl Zeiss, Jena, Germany) and Cs-corrected FEI Titan 80-300 kV highresolution transmission electron microscopy operated at an acceleration voltage of 80 and $300 \mathrm{kV}$ (FEI, Eindhoven, The Netherlands). The elemental distribution was investigated using an energy-dispersive X-ray spectrometer (Oxford Instruments, Munich, Germany). Thermal gravimetric analysis was performed using a thermogravimetric analyzer (TGA-209F, Netzsch, Selb, Germany) under $\mathrm{O}_{2}$ flow of $20 \mathrm{ml} \mathrm{min}^{-1}$ within the temperature range of 30$600{ }^{\circ} \mathrm{C}$ (final materials) and $30-800{ }^{\circ} \mathrm{C}$ (precursors) at a $5{ }^{\circ} \mathrm{C} \mathrm{min}-1$ scan rate. Tap density measurements were performed on a tap density analyzer (Autotap, Quantachrome, Boynton Beach, FL, USA), with 1000 taps per sample.

\section{Electrochemical characterization}

The electrochemical tests were performed using three electrode Swagelok-type cells assembled in an argon-filled glove box. Sodium half-cells were assembled by using glass fiber filters (Whatman, Maidstone, UK) as separators soaked in various electrolyte solutions and sodium metal as the counter and reference electrodes. The $1 \mathrm{~m}$ solution of $\mathrm{NaPF}_{6}(99 \%$, Alfa Aesar) in ethylene carbonate/ diethyl carbonate (1:1 w/w) (BASF, Ludwigshafen, Germany, Battery Grade) and the $10 \mathrm{~mol} \%$ solution of NaTFSI (sodium bis(trifluoromethanesulfonyl) imide, 99.5\%, SOLVIONIC, Varilhes, France) in $\mathrm{Py}_{14} \mathrm{FSI}$ (N-butyl- $N$-methylpyrrolidinium bis(fluorosulfonyl)imide) were used as electrolytes. Sodium metal was cut from sodium pieces (99.8\%, Acros Organics, Morris Plains, NJ, USA), roll-pressed and punched on the current collector. The electrodes were prepared by doctor-blade casting a slurry prepared by dispersing $80 \mathrm{wt} \%$ of active material, $10 \mathrm{wt} \%$ of carbon black as conductive agent (Super C65, IMERYS, Bodio, Switzerland) and $10 \mathrm{wt} \%$ of polyvinylidenefluoride $(6020$ Solef, Arkema Group, Paris, France) binder in N-methyl-2-pyrrolidone (anhydrous, 99.5\%, Sigma-Aldrich, St Louis, MO, USA) on Al foil as the current collector. After drying, electrodes with a $12 \mathrm{~mm}$ diameter were punched, pressed and dried again. The mass loading was $\sim 2.8 \mathrm{mg} \mathrm{cm}^{-2}$. The cells were assembled in an argon-filled glove box with $\mathrm{H}_{2} \mathrm{O}$ and $\mathrm{O}_{2}$ contents < 1 p.p.m. A Maccor 4000 Battery system (Maccor, Tulsa, OK, USA) was used for the galvanostatic charge/discharge test between 3.0 and $4.9 \mathrm{~V}$ vs $\mathrm{Na}^{+} / \mathrm{Na}$ in the organic electrolyte and between 3.0 and $5.1 \mathrm{~V} \mathrm{vs} \mathrm{Na} / \mathrm{Na}$ in the ionic liquid electrolyte at a current density of $10 \mathrm{~mA} \mathrm{~g}^{-1}$. Cyclic voltammetry was performed on a multichannel potentiostat/galvanostat (VMP3, Biologic Science Instruments, Claix, France) using a scan rate of 0.01, 0.05, 0.1 and $0.5 \mathrm{mV} \mathrm{s}^{-1}$ in a voltage range of $3.0-5.0 \mathrm{~V} \mathrm{vs} \mathrm{Na}^{+} / \mathrm{Na}$ (organic electrolyte) and $3.0-5.2 \mathrm{~V} \mathrm{vs} \mathrm{Na}^{+} / \mathrm{Na}$ (ionic liquid electrolyte). All the potential values in this study are in reference to the $\mathrm{Na}^{+} / \mathrm{Na}$ reference electrode. All measurements were performed in climatic chambers at a temperature of $20 \pm 1{ }^{\circ} \mathrm{C}$.

\section{RESULTS AND DISCUSSION}

The structural properties of the $\mathrm{Na}_{4} \mathrm{Ni}_{3}\left(\mathrm{PO}_{4}\right)_{2}\left(\mathrm{P}_{2} \mathrm{O}_{7}\right)$ have been determined by XRD analysis. Figure 1 shows the Rietveld refinement and the schematic representation of the crystal structure deduced for $\mathrm{Na}_{4} \mathrm{Ni}_{3}\left(\mathrm{PO}_{4}\right)_{2}\left(\mathrm{P}_{2} \mathrm{O}_{7}\right)$. Rietveld refinement of the powder XRD pattern confirms that the $\mathrm{Na}_{4} \mathrm{Ni}_{3}\left(\mathrm{PO}_{4}\right)_{2}\left(\mathrm{P}_{2} \mathrm{O}_{7}\right)$ is isostructural to $\mathrm{Na}_{4} \mathrm{Fe}_{3}\left(\mathrm{PO}_{4}\right)_{2}\left(\mathrm{P}_{2} \mathrm{O}_{7}\right)$ and crystallizes in the orthorhombic $P n 2_{1} a$ space group with $a=18.0006(3) \AA, b=6.4933(1) \AA$ and $c=10.4115(2) \AA$. The refinement has been performed with satisfactory agreement factors $\left(R_{\mathrm{wp}}=4.79 \%, R_{\mathrm{p}}=3.45 \%\right.$, goodness of fit $\left.=2.13\right) \quad(\mathrm{ICSD}$ (Inorganic Crystal Structure Database) 236316). ${ }^{27}$ The diffractogram reported in Figure 1a presents no evidence of impurity phases, suggesting that the synthesis conditions adopted are suitable for obtaining pure $\mathrm{Na}_{4} \mathrm{Ni}_{3}\left(\mathrm{PO}_{4}\right)_{2}\left(\mathrm{P}_{2} \mathrm{O}_{7}\right)$. The refined cell parameters and atomic occupancy values are summarized and presented, respectively, in Supplementary Tables S1 and S2 . Rietveld refinement of the XRD pattern of the carbon-coated analog $\left(\mathrm{Na}_{4} \mathrm{Ni}_{3}\left(\mathrm{PO}_{4}\right)_{2}\left(\mathrm{P}_{2} \mathrm{O}_{7}\right) / \mathrm{C}\right)$ (Supplementary Figure S2) shows that the carbon coating process has no effect on the structural characteristics of the material that crystallizes in the same space group with comparable cell parameters. The crystal structures of $\mathrm{Na}_{4} \mathrm{Ni}_{3}\left(\mathrm{PO}_{4}\right)_{2}\left(\mathrm{P}_{2} \mathrm{O}_{7}\right)$ viewed along the [001] and [010] directions are displayed in Figure 1b. As the isostructural $\mathrm{Na}_{4} \mathrm{Co}_{3}\left(\mathrm{PO}_{4}\right)_{2}\left(\mathrm{P}_{2} \mathrm{O}_{7}\right)$ and $\mathrm{Na}_{4} \mathrm{Fe}_{3}\left(\mathrm{PO}_{4}\right)_{2}\left(\mathrm{P}_{2} \mathrm{O}_{7}\right)$, the crystal structure of $\mathrm{Na}_{4} \mathrm{Ni}_{3}\left(\mathrm{PO}_{4}\right)_{2}\left(\mathrm{P}_{2} \mathrm{O}_{7}\right)$ is composed of three-dimensional network layers of $\left[\mathrm{Ni}_{3} \mathrm{P}_{2} \mathrm{O}_{13}\right]_{\infty}$ jointly composed by $\mathrm{NiO}_{6}$ octahedra and 


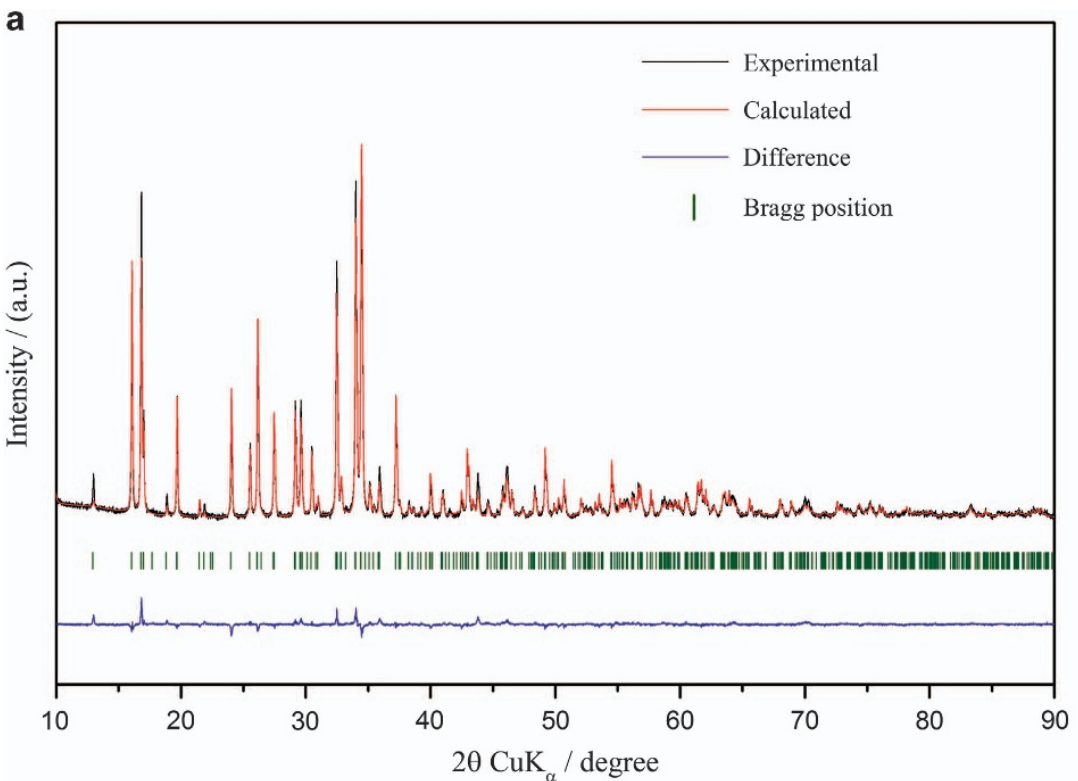

b
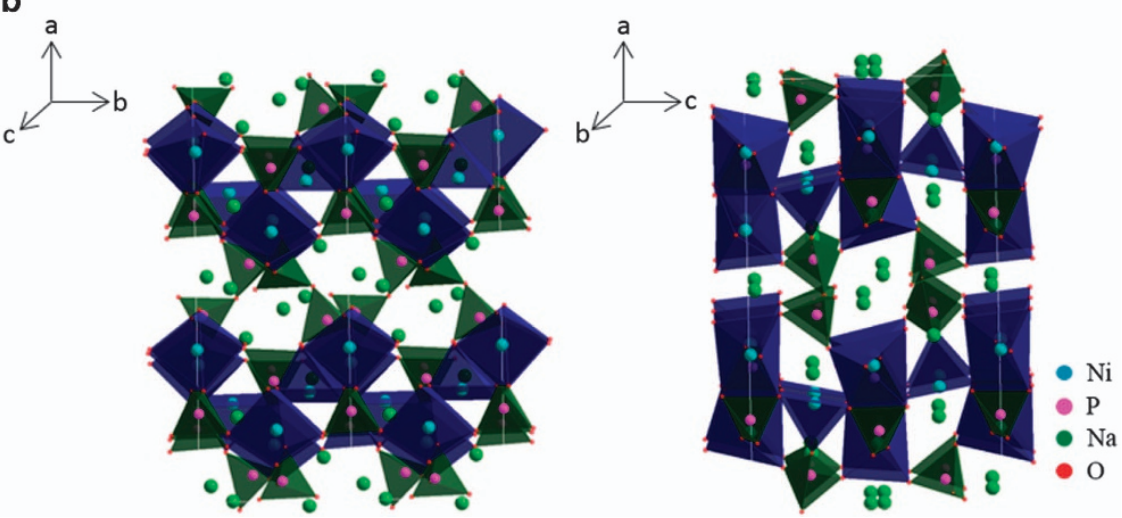

Figure 1 (a) Rietveld refinement and powder X-ray diffraction (XRD) for $\mathrm{Na}_{4} \mathrm{Ni}_{3}\left(\mathrm{PO}_{4}\right)_{2}\left(\mathrm{P}_{2} \mathrm{O}_{7}\right)$. (b) Schematic representation of the crystal structure of $\mathrm{Na}_{4} \mathrm{Ni}_{3}$ $\left(\mathrm{PO}_{4}\right)_{2}\left(\mathrm{P}_{2} \mathrm{O}_{7}\right)$ viewed along the [001] and [010] directions.

$\left(\mathrm{PO}_{4}\right)^{3-}$ tetrahedra in the $b c$ plane that are bridged by the $\left(\mathrm{P}_{2} \mathrm{O}_{7}\right)^{4-}$ dimers generating large channels along the $b$-axis with a low activation barrier energy for $\mathrm{Na}^{+}$ion diffusion. ${ }^{23,29}$ The $\mathrm{Na}$ ions occupy four distinguishable sites, among which two ( $\mathrm{Nal}$ and $\mathrm{Na} 4$ ) are located in the large channels parallel to the $b$-axis. The Ni-based polyanionic materials have so far been considered as an electrochemically inactive cathode material in both $\mathrm{Li}$ and $\mathrm{Na}$ systems because of the low electronic conductivity resulting in the poor alkali ion diffusion activity. ${ }^{12}$ However, in this study, the structure deriving from the mixed polyanionic $\mathrm{Na}_{4} \mathrm{Ni}_{3}\left(\mathrm{PO}_{4}\right)_{2}\left(\mathrm{P}_{2} \mathrm{O}_{7}\right)$ may stabilize the charged $\mathrm{Ni}$ analog and open pathways for the improved and reversible $\mathrm{Na}^{+}$ diffusion with respect to the $\mathrm{NaNiPO}_{4}$ and $\mathrm{Na}_{2} \mathrm{NiP}_{2} \mathrm{O}_{7}$ polyanionic materials that can contribute to the improved electrochemical reactivity.

Scanning electron microscopy and high-resolution transmission electron microscopy analyses were conducted to assess the morphological and structural aspects of the synthesized powders. Figures $2 \mathrm{a}$ and $\mathrm{b}$ present the scanning electron microscopy images of $\mathrm{Na}_{4} \mathrm{Ni}_{3}$ $\left(\mathrm{PO}_{4}\right)_{2}\left(\mathrm{P}_{2} \mathrm{O}_{7}\right)$ and $\mathrm{Na}_{4} \mathrm{Ni}_{3}\left(\mathrm{PO}_{4}\right)_{2}\left(\mathrm{P}_{2} \mathrm{O}_{7}\right) / \mathrm{C}$. As shown in Figure $2 \mathrm{a}$, the pristine $\mathrm{Na}_{4} \mathrm{Ni}_{3}\left(\mathrm{PO}_{4}\right)_{2}\left(\mathrm{P}_{2} \mathrm{O}_{7}\right)$ aggregates in shapeless micrometric particles (that is, polymorphic morphology). After the carbon coating treatment, the particle size of the powder is favorably reduced with well-defined edges. The tap density of carbon-coated $\mathrm{Na}_{4} \mathrm{Ni}_{3}\left(\mathrm{PO}_{4}\right)_{2}$
$\left(\mathrm{P}_{2} \mathrm{O}_{7}\right)$ material is $\sim 1.01 \mathrm{~g} \mathrm{~cm}^{-3}$, that is, smaller than the tap density of the pristine $\mathrm{Na}_{4} \mathrm{Ni}_{3}\left(\mathrm{PO}_{4}\right)_{2}\left(\mathrm{P}_{2} \mathrm{O}_{7}\right)$ material at $1.24 \mathrm{~g} \mathrm{~cm}^{-3}$, that can be attributed to the reduced particle size and the carbon coating. The elemental mapping by energy-dispersive X-ray spectroscopy of $\mathrm{Na}$, $\mathrm{Ni}, \mathrm{O}, \mathrm{P}$ and $\mathrm{C}$ has been performed to check the metal element distribution in $\mathrm{Na}_{4} \mathrm{Ni}_{3}\left(\mathrm{PO}_{4}\right)_{2}\left(\mathrm{P}_{2} \mathrm{O}_{7}\right)$ (Supplementary Figure S3). The analysis reveals a homogeneous distribution of the elements investigated, confirming the elemental composition. The transition electron microscopy analysis of $\mathrm{Na}_{4} \mathrm{Ni}_{3}\left(\mathrm{PO}_{4}\right)_{2}\left(\mathrm{P}_{2} \mathrm{O}_{7}\right) / \mathrm{C}$, reported in Figure $2 \mathrm{c}$, confirms the shapeless character of the particles, showing a submicrometric dimension with an average diameter of $\sim 500 \mathrm{~nm}$. In addition, the high-resolution transmission electron microscopy image in Figure 2d clearly shows a lattice fringe of $d=0.680 \mathrm{~nm}$, corresponding to the (201) plane diffraction of $\mathrm{Na}_{4} \mathrm{Ni}_{3}\left(\mathrm{PO}_{4}\right)_{2}\left(\mathrm{P}_{2} \mathrm{O}_{7}\right) / \mathrm{C}$. This material shows structural instability under an intense electron beam demonstrated by the disappearance of the lattice fringe after a prolonged electron beam irradiation (Supplementary Figure S4), opening the question about the crystal stability of the mixed polyanionic structure under nonconventional conditions. ${ }^{30}$ Thermal gravimetric analysis (Supplementary Figure S5) was performed to investigate the thermal stability and carbon content of the prepared materials. The thermogram of pristine $\mathrm{Na}_{4} \mathrm{Ni}_{3}\left(\mathrm{PO}_{4}\right)_{2}\left(\mathrm{P}_{2} \mathrm{O}_{7}\right)$ shows a 


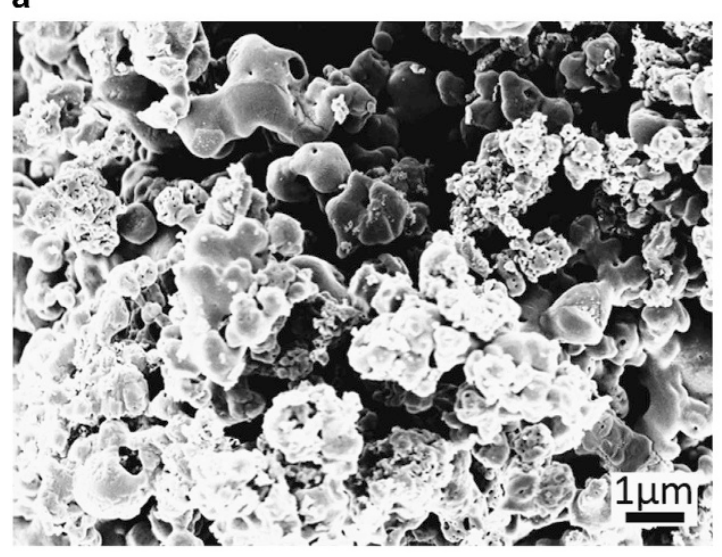

b

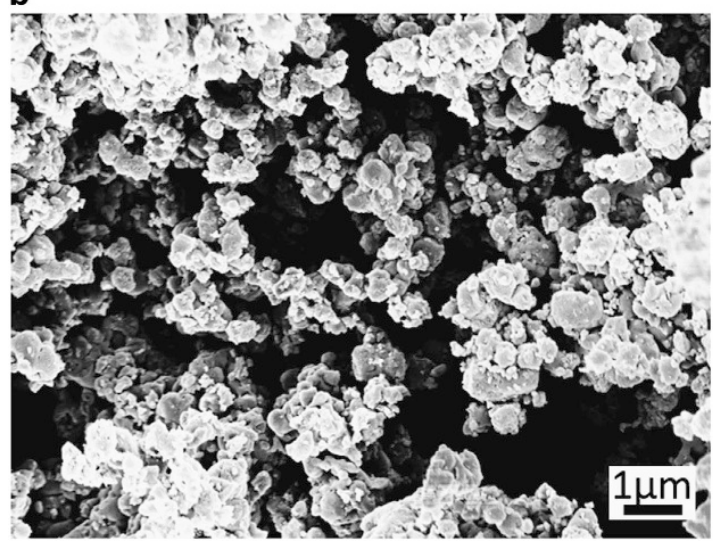

C

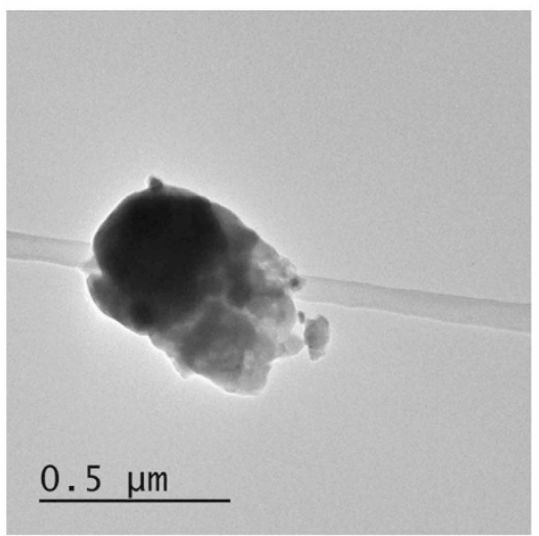

d

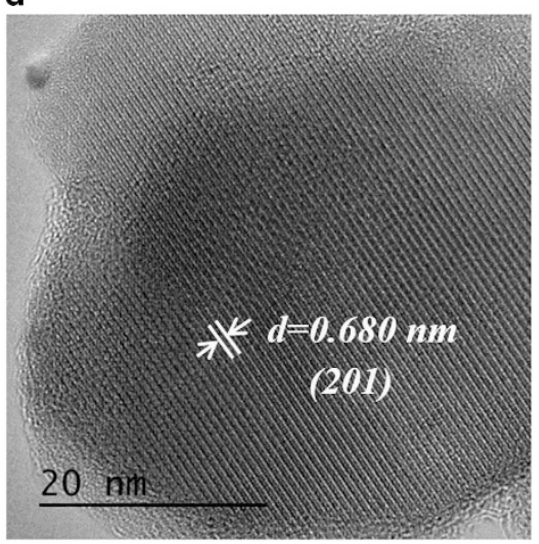

Figure 2 Scanning electron microscopy (SEM) images of (a) $\mathrm{Na}_{4} \mathrm{Ni}_{3}\left(\mathrm{PO}_{4}\right)_{2}\left(\mathrm{P}_{2} \mathrm{O}_{7}\right)$ and (b) $\mathrm{Na}_{4} \mathrm{Ni}_{3}\left(\mathrm{PO}_{4}\right)_{2}\left(\mathrm{P}_{2} \mathrm{O}_{7}\right) / \mathrm{C}$ powders. (c, d) Transmission electron microscopy (TEM) images of $\mathrm{Na}_{4} \mathrm{Ni}_{3}\left(\mathrm{PO}_{4}\right)_{2}\left(\mathrm{P}_{2} \mathrm{O}_{7}\right) / \mathrm{C}$ performed on an FEI Titan 80-300 kV electron microscope with image Cs-corrector at an accelerating voltage of $80 \mathrm{kV}$.

slight weight loss before $100^{\circ} \mathrm{C}$, attributable most likely to water desorption. The weight loss detected from $300^{\circ} \mathrm{C}$ is related to the oxidation of residual carbon belonging to the organic salt precursor. Meanwhile, no weight loss is observed after $500{ }^{\circ} \mathrm{C}$, even when exposed in $\mathrm{O}_{2}$, reflecting a considerably high thermal stability. The content of absorbed water in the carbon-coated material is higher than in the pristine material, suggesting a higher sensitivity to moisture, most likely because of a higher surface area. The carbon content is calculated as $\sim 6.3 \%$ that corresponds to the weight detected within the $100-450^{\circ} \mathrm{C}$ temperature range.

The investigation of $\mathrm{Ni}$ redox activity in the polyanionic framework has been performed by galvanostatic cycling tests and cyclic voltammetry analysis. In an attempt to study the effect of the polyanionic framework in the $\mathrm{Ni}$ redox couple, three different Ni-based compounds were synthesized, that is, $\mathrm{NaNiPO}_{4}$ (the phosphate), $\mathrm{Na}_{2} \mathrm{NiP}_{2} \mathrm{O}_{7}$ (the pyrophosphate) and $\mathrm{Na}_{4} \mathrm{Ni}_{3}\left(\mathrm{PO}_{4}\right)_{2}$ $\left(\mathrm{P}_{2} \mathrm{O}_{7}\right)$ (the mixed polyanionic compound). $\mathrm{Na}_{2} \mathrm{NiP}_{2} \mathrm{O}_{7}$ and $\mathrm{NaNiPO}_{4}$ polyanionic compounds have been prepared using the same solid-state method. As the Fe-based compound, the stoichiometric $\mathrm{Na}_{2} \mathrm{NiP}_{2} \mathrm{O}_{7}$ crystallizes in the triclinic $P-1$ space group. The XRD pattern obtained is shown in Supplementary Figure S6a. $\mathrm{NaNiPO}_{4}$ has also been prepared according to the synthesis conditions reported in the Supplementary Information. However, orthorhombic $\mathrm{Na}_{4} \mathrm{Ni}_{3}\left(\mathrm{PO}_{4}\right)_{2}$ $\left(\mathrm{P}_{2} \mathrm{O}_{7}\right)$ was obtained instead of maricite $\mathrm{NaNiPO}_{4}$ (the XRD pattern obtained is presented in Supplementary Figure $\mathrm{S} 6 \mathrm{~b}$ ), reflecting the thermodynamic stability of the $\mathrm{Na}_{4} \mathrm{Ni}_{3}\left(\mathrm{PO}_{4}\right)_{2}\left(\mathrm{P}_{2} \mathrm{O}_{7}\right)$ phase under our experimental conditions.
To investigate the electrochemical processes occurring during sodium (de-)insertion, the carbon-coated materials have been selected as the material of choice, owing to its enhanced conductivity with respect to the pristine material. ${ }^{31}$ Moreover, in an attempt to enlarge the electrochemical stability window of the electrolyte and enable the investigation of the $\mathrm{Ni}$ redox activity at higher potential values, an ionic liquid-based electrolyte, that is, NaTFSI in $\mathrm{Py}_{13} \mathrm{FSI}$ (1:9 in mole ratio), was employed. ${ }^{32,33}$ A comparative electrochemical investigation between the carbon-coated $\mathrm{Na}_{4} \mathrm{Ni}_{3}\left(\mathrm{PO}_{4}\right)_{2}\left(\mathrm{P}_{2} \mathrm{O}_{7}\right)$ and $\mathrm{Na}_{2} \mathrm{NiP}_{2} \mathrm{O}_{7}$ is shown in Figure 3, showing the differential capacity vs voltage (dQ/dV) curves of $\mathrm{Na}_{4} \mathrm{Ni}_{3}\left(\mathrm{PO}_{4}\right)_{2}\left(\mathrm{P}_{2} \mathrm{O}_{7}\right) / \mathrm{C}$ and $\mathrm{Na}_{2} \mathrm{Ni}\left(\mathrm{P}_{2} \mathrm{O}_{7}\right) / \mathrm{C}$. The $\mathrm{dQ} / \mathrm{dV}$ curve of $\mathrm{Na}_{4} \mathrm{Ni}_{3}\left(\mathrm{PO}_{4}\right)_{2}\left(\mathrm{P}_{2} \mathrm{O}_{7}\right) / \mathrm{C}$ shows three anodic peaks at $4.61,4.67$ and $5.00 \mathrm{~V}$ with two reversible cathodic peaks at 4.58 and $4.92 \mathrm{~V}$, elucidating the redox activity of the $\mathrm{Ni}$ redox couple in a sodium cell accompanied by reversible $\mathrm{Na}$ ion (de-)insertion. For the $\mathrm{dQ} / \mathrm{dV}$ curve of the $\mathrm{Na}_{2} \mathrm{NiP}_{2} \mathrm{O}_{7} / \mathrm{C}$ electrode, no electrochemical activity is observed, suggesting that $\mathrm{Ni}$ is not active in the pyrophosphate framework under our experimental conditions. From the comparison, it is incidentally determined that the mixed phosphate frameworks enable the $\mathrm{Ni}^{2+/ 3+}$ redox activity in polyanionic structures compared with those of pyrophosphates.

To further understand the sodium (de-)insertion process associated with the Ni activity in such a framework, cyclic voltammetry and charging/discharging measurements were performed with NaTFSI in $\mathrm{Py}_{13} \mathrm{FSI}$ (1:9 mole ratio) electrolyte, and the corresponding results are shown in Figures $4 \mathrm{a}$ and $\mathrm{b}$. The cyclic voltammetry profile shown in Figure $4 \mathrm{a}$ exhibits three anodic peaks at $4.61,4.67$, and $5.00 \mathrm{~V}$ and 


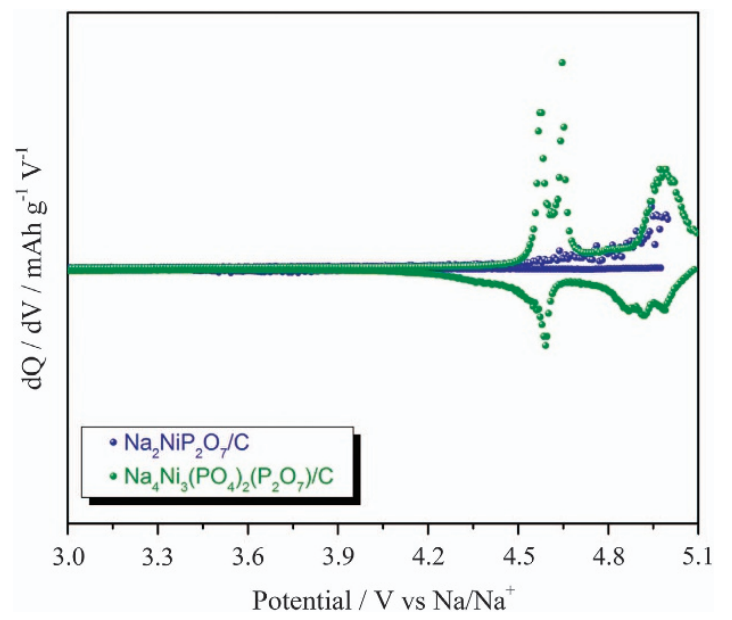

Figure 3 Initial differential capacities vs potential (dQ/dV) curves of the $\mathrm{Na}_{4} \mathrm{Ni}_{3}\left(\mathrm{PO}_{4}\right)_{2}\left(\mathrm{P}_{2} \mathrm{O}_{7}\right) / \mathrm{C}$ and $\mathrm{Na}_{2} \mathrm{NiP}_{2} \mathrm{O}_{7} / \mathrm{C}$ in the $\mathrm{NaTFSI}: \mathrm{Py}_{13} \mathrm{FSI}$ (1:9 mole ratio) electrolyte at a current density of $10 \mathrm{~mA} \mathrm{~g}^{-1}$.

only two cathodic peaks at 4.58 and $4.92 \mathrm{~V}$, in accordance with the $\mathrm{dQ} / \mathrm{dV}$ profile reported in Figure 3. The potential profile reported in Figure $4 \mathrm{~b}$ reveals the de-insertion of $2.7 \mathrm{Na}$ equivalents followed by the insertion of $1.3 \mathrm{Na}$ equivalents, corresponding to a discharge capacity of $63 \mathrm{mAh} \mathrm{g}^{-1}$, representing a promising degree of reversibility for this unexplored material. However, based on the $\mathrm{Ni}^{2+/ 3+}$ redox reaction, a theoretical capacity of $127.2 \mathrm{mAh} \mathrm{g}^{-1}$ is expected, referring to 3 equivalents of $\mathrm{Na}^{+}$. The investigation of a wide potential window shows clearly that there is no further redox process at potentials higher than $5.0 \mathrm{~V}$. In addition, electrolyte decomposition, aluminum current collector corrosion and possible oxidation of the carbon deriving from the carbon coating process, which may also affect the cycling performance, cannot be excluded at such high potential values vs $\mathrm{Na}^{+} / \mathrm{Na}^{34,35}$ Cyclic voltammetry tests have also been performed in standard carbonate-based electrolyte $\left(1 \mathrm{M} \mathrm{NaPF}_{6}\right.$ in ethylene carbonate/diethyl carbonate, 1:1 w/w) (see Supplementary Figure S7). The cyclic voltammetry curves obtained at various scan rates (Supplementary Figure S7a) confirm the reversibility of the sodium (de-)insertion also at higher scan rates, despite the increased cell polarization. This observation is in good agreement with the charge/discharge voltage profile (Supplementary Figure S7b), suggesting a reversible redox process occurring at such a high working potential. The material reveals a satisfactory cycling stability. However, the redox peaks decrease upon cycling, most likely because of poor kinetics. More detailed description and discussion can be found in the Supplementary Information section. Regardless of its high working potential, the material exhibits relatively low coulombic efficiency and poor specific capacity compared with other reported $\mathrm{Fe}-$ or Co-based polyanionic compounds in both organic and ionic liquid electrolytes. ${ }^{36,37}$ The inferior electrochemical behavior of the $\mathrm{Ni}$-based compound with respect to $\mathrm{Fe}$ - and Co-based analogs may be attributed to the intrinsic lower ionic conductivity of the former material. Sanz et al. ${ }^{12}$ have reported that the Ni-based compound exhibits the lowest ionic conductivity of $\sim 2.1 \times 10^{-7} \mathrm{~S} \mathrm{~cm}^{-1}$ at $300^{\circ} \mathrm{C}$, with respect to $\mathrm{Fe}, \mathrm{Mn}$ and $\mathrm{Co}$.

Potential profiles and cycling performance of $\mathrm{Na}_{4} \mathrm{Ni}_{3}\left(\mathrm{PO}_{4}\right)_{2}\left(\mathrm{P}_{2} \mathrm{O}_{7}\right) / \mathrm{C}$ in both carbonate- and ionic liquid-based electrolytes are presented in Supplementary Figure S8. The profiles reveal first discharge capacities of $\sim 40$ and $63 \mathrm{mAh} \mathrm{g}^{-1}$, respectively, in carbonate-based $(3.0$ to $4.9 \mathrm{~V})$ and ionic liquid-based ( 3.0 to $5.1 \mathrm{~V}$ ) electrolytes. However, the wider potential window inevitably leads to lower coulombic efficiencies
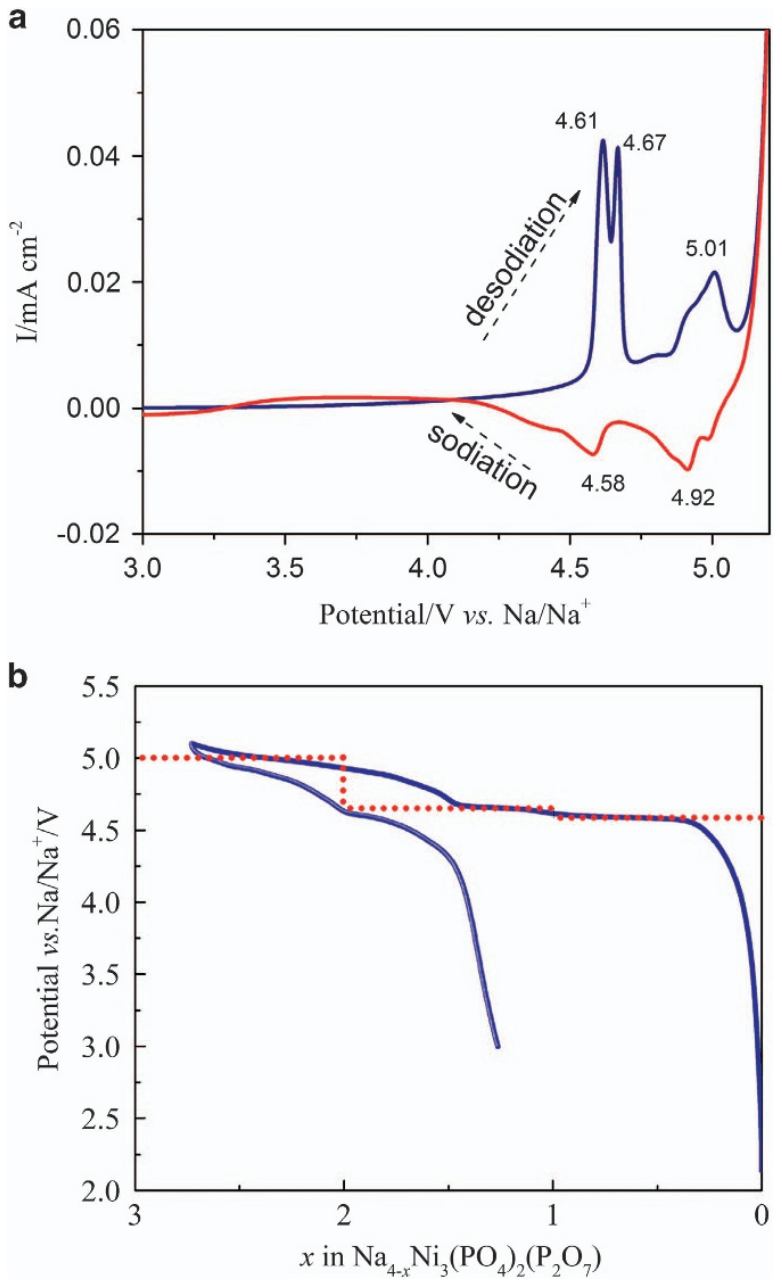

Figure 4 Cyclic voltammetry curve in the potential range of $3.0-5.2 \mathrm{~V}$ at a scan rate of $0.01 \mathrm{mV} \mathrm{s}^{-1}$ (a) and first cycle galvanostatic discharge/charge profile between 3.0 and $5.1 \mathrm{~V}$ at a current density of $10 \mathrm{mAg}^{-1}$ (b) of $\mathrm{Na}_{4} \mathrm{Ni}_{3}\left(\mathrm{PO}_{4}\right)_{2}\left(\mathrm{P}_{2} \mathrm{O}_{7}\right) / \mathrm{C}$ in NaTFSI:Py ${ }_{13} \mathrm{FSI}$ (1:9 mole ratio) electrolyte.

because of oxidative decomposition reactions. As an example, at the highest potential (that is, $5.1 \mathrm{~V}$ vs $\mathrm{Na}^{+} / \mathrm{Na}$, corresponding to $5.4 \mathrm{~V}$ vs $\mathrm{Li}^{+} / \mathrm{Li}$ ), the decomposition of $\mathrm{Py}_{13} \mathrm{FSI}$ ionic liquid is known to occur. ${ }^{33}$ The conductive agent, Super C65, is playing a role at such potential values. The use of carbon nanotubes, for example, results in the $25 \%$ discharge capacity increase in carbonate-based electrolyte (see Supplementary Figure S9). However, extensive electrolyte decomposition occurs, resulting in an overall lower coulombic efficiency. A different electrode current collector (aluminum) and binder may also be used. For example, higher anodic stability $\left(\sim 5.5 \mathrm{~V}\right.$ vs $\left.\mathrm{Na}^{+} / \mathrm{Na}\right)$ was reported using polytetrafluoroethylene as a binder, carbon paper as the current collector and $0.5 \mathrm{M}$ NaTFSI in Py $y_{13}$ TFSI as the electrolyte. However, oxidative decomposition would always occur. ${ }^{38}$

To better understand the factors affecting the electrochemical performance exhibited, further structural investigation has been performed. It has been proposed that structural reorganization upon cycling could affect the reversibility of the sodium (de-)insertion. Indeed, the structural changes during $\mathrm{Na}$ (de-)insertion may derive from the instability of the desodiated electrode, most likely because of the distortion of $\mathrm{P}_{2} \mathrm{O}_{7}$ dimers and changes in the unit cell volume. ${ }^{8,23}$

The investigation of the $\mathrm{Na}$ (de-)insertion mechanism in the $\mathrm{Na}_{4} \mathrm{Ni}_{3}$ $\left(\mathrm{PO}_{4}\right)_{2}\left(\mathrm{P}_{2} \mathrm{O}_{7}\right) / \mathrm{C}$ electrode was carried out by ex situ XRD 

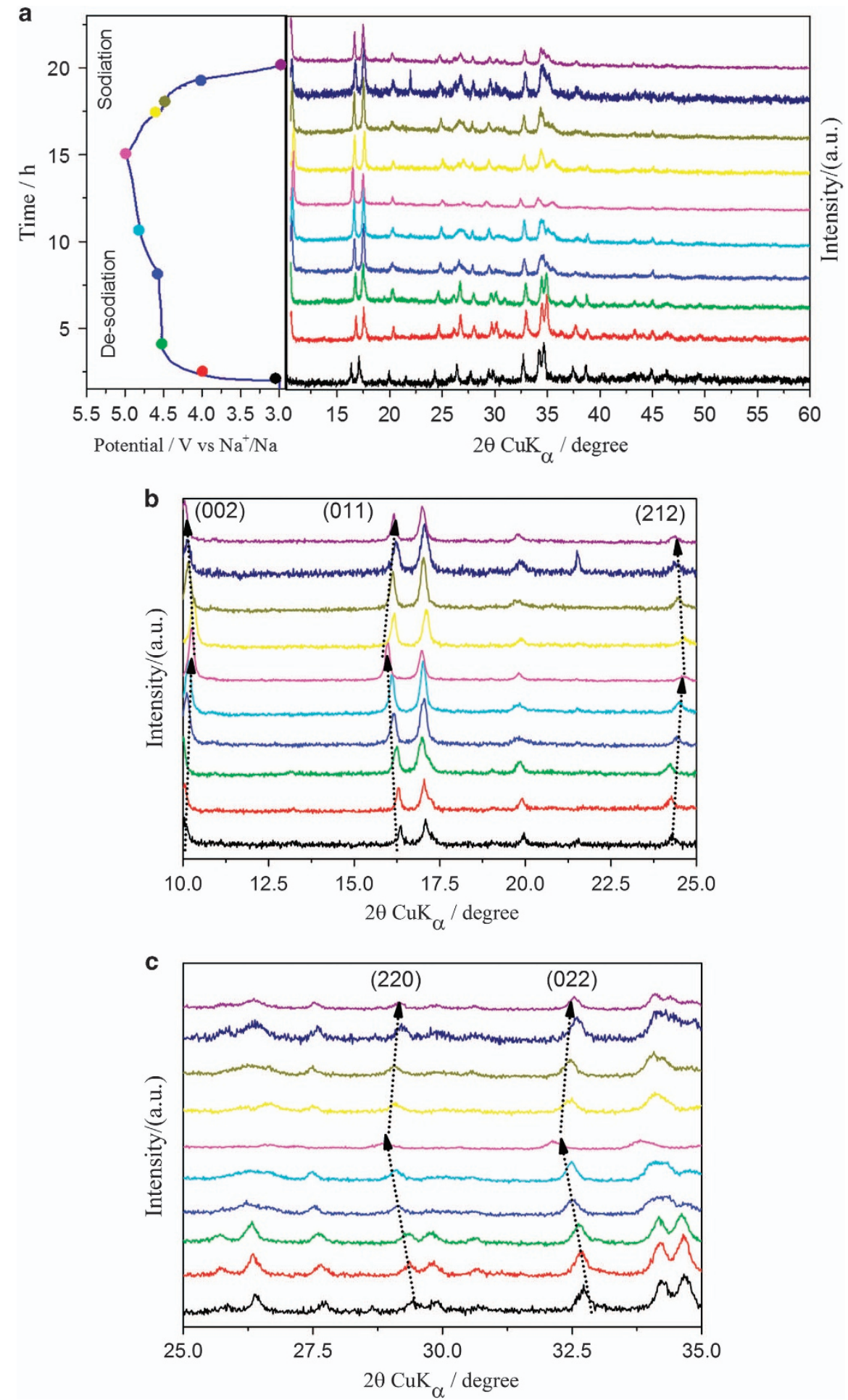

Figure 5 (a) Typical charge/discharge profile and ex situ X-ray diffraction (XRD) pattern of the $\mathrm{Na}_{4} \mathrm{Ni}_{3}\left(\mathrm{PO}_{4}\right)_{2}\left(\mathrm{P}_{2} \mathrm{O}_{7}\right) / \mathrm{C}$ electrode at various charge and discharge states. (b, c) Amplified XRD patterns in the $2 \theta$ range of $10-25^{\circ}$ and $25-35^{\circ}$, respectively.

measurements at different states of charge. Figure $5 \mathrm{a}$ displays the typical charge/discharge profile of a Na/Na $\mathrm{Ni}_{4}\left(\mathrm{NO}_{4}\right)_{2}\left(\mathrm{P}_{2} \mathrm{O}_{7}\right) / \mathrm{C}$ cell with points and letters indicating the potential values at which $\mathrm{XRD}$ analysis has been performed. When charging the electrode to $5.0 \mathrm{~V}$ in the ethylene carbonate/diethyl carbonate-based electrolyte, the initial charge capacity is higher than the theoretical capacity that, at such a high working potential, may be attributed to the cathode-electrolyte interface film formation of the Ni-based electrode materials and oxidative electrolyte decomposition..$^{39,40}$ The patterns collected in the $10-60^{\circ} 2 \theta$ range are displayed in Figure $5 \mathrm{a}$. The main reflections of the mixed polyanionic phase are shown to be maintained upon charge and discharge, whereas moderate peak shifting and intensity changes occur, suggesting that neither phase transition nor irreversible structural reorganization occurs upon sodium de-insertion. The 
amplified XRD patterns in the $2 \theta$ range of $10-25^{\circ}$ and $25-35^{\circ}$ in Figures $5 \mathrm{~b}$ and $\mathrm{c}$ clearly show the peak shifts during the electrochemical reaction. Interestingly, although the (200) peak at $\sim 10^{\circ}$ is
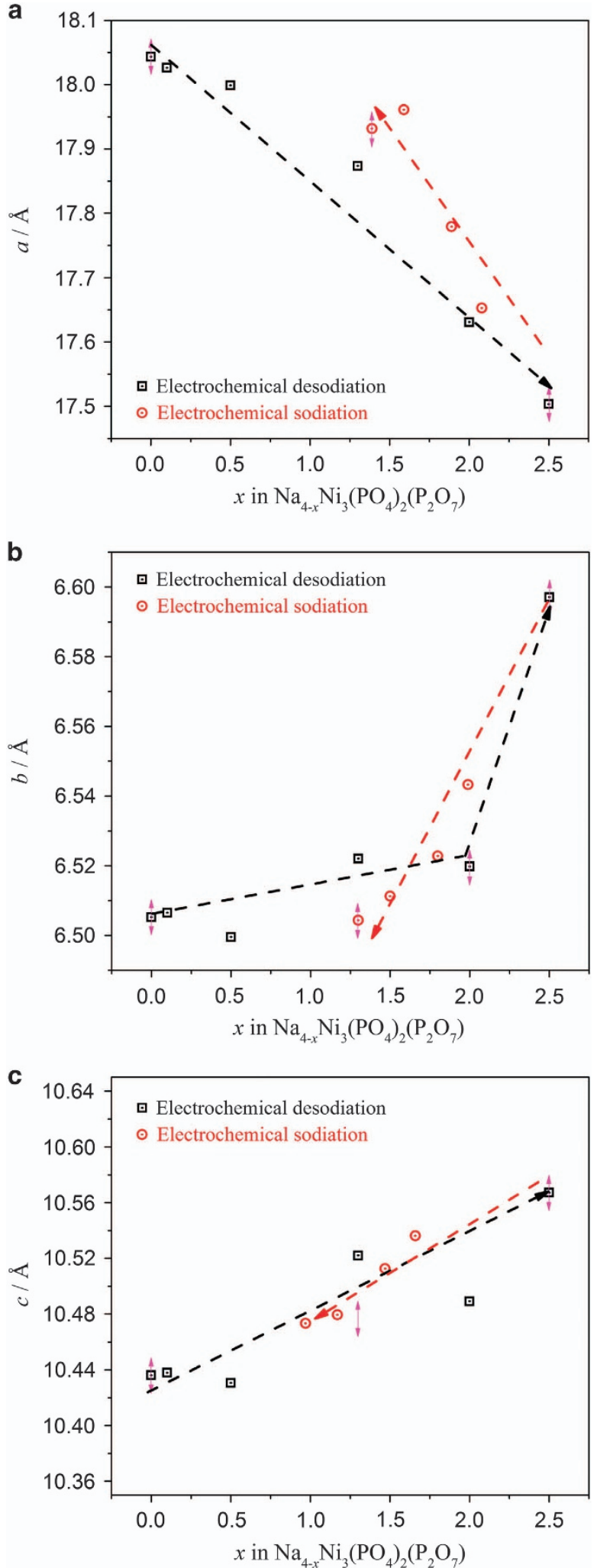

Figure 6 Lattice parameter $(a, b, c)$ change during electrochemical desodiation/sodiation process. moving to a higher $2 \theta$ value, other major peaks such as (011), (111), (220) and (022) show a slight shift to lower $2 \theta$ when the $\mathrm{Na}$ is extracted from the host material. During the discharge process, the peaks gradually move back to the original positions, suggesting the reversibility of the structural modifications associated with the volume change during the $\mathrm{Na}$ (de-)insertion process. To investigate the occupancy of the four different $\mathrm{Na}$ atoms upon sodium (de-)insertion, Rietveld refinement of the ex situ XRD results has been performed. The evolution of the refined lattice parameters $(a, b, c)$ is shown in Figures $6 \mathrm{a}-\mathrm{c}$. The $a$ lattice parameter value instantaneously decreases when the $\mathrm{Na}$ ions are electrochemically removed from the crystal structure, whereas the $b$ and $c$ axis parameters increase. The results herein presented differ slightly from those already reported for the Fe-based analog system, suggesting different structural changes in the potential range investigated. ${ }^{26,27}$ The $\mathrm{Na}$ occupancies, reported in Table S3, indicate that the sodium cations located in the large channels constructed by the $\mathrm{P}_{2} \mathrm{O}_{7}$ dimers, that is, the $\mathrm{Nal}$ and $\mathrm{Na} 4$ sites, can be electrochemically removed first at relatively low potentials, resulting in the decrease of the $a$ lattice parameter and leading to a volume change of $1.6 \%$. When charging up to $5.0 \mathrm{~V}$, the other two sodium cations, that is, from $\mathrm{Na} 2$ and $\mathrm{Na} 3$ sites, are extracted subsequently, leading to the rapid increase in the $b$ parameter. When discharged back to $3.0 \mathrm{~V}$, the observed lattice parameters are slightly different from those of the pristine sample, suggesting a not fully reversible electrochemical process, indicated as well by the electrochemical characterization above. The low reversibility may be ascribed to the collapse of $\left[\mathrm{Ni}_{3} \mathrm{P}_{2} \mathrm{O}_{13}\right]_{\infty}$ layers along the $a$ axis to a certain extent blocking the $\mathrm{Na}$ diffusion channels that confirms the instability of the desodiated electrode and reflects the low columbic efficiency of the chargedischarge process. However, the superior thermal stability and small volume changes during cycling of the material demonstrate the advantages of using mixed polyanionic structures to construct a large diffusion channel for $\mathrm{Na}$ ions, proving this strategy to be an efficient way to develop Ni-based polyanionic materials as conceivable high voltage cathodes.

The integration of the two framework types in the same lattice, namely the $\left[\mathrm{PO}_{4}\right]$ and $\left[\mathrm{P}_{2} \mathrm{O}_{7}\right]$ groups, enables the electrochemical activity of the $\mathrm{Ni}^{2+/ 3+}$ redox reaction at high potential. This study represents a step forward in the design of high voltage cathode materials for Na-ion batteries. However, this research field faces several challenges. Electrochemically stable electrolytes and/or electrolyte additives, forming a cathode-electrolyte interphase with protective (electronic insulating, but ion-conducting) properties, thus mitigating or avoiding oxidative decomposition reactions, should be identified to enable such high voltage cathode materials in Na-ion batteries.

\section{CONCLUSIONS}

In summary, the $\mathrm{Ni}^{2+/ 3+}$ redox activity in the mixed polyanionic framework has been experimentally demonstrated for the first time in sodium cells. Contrary to the pyrophosphate structure $\left(\mathrm{Na}_{2} \mathrm{NiP}_{2} \mathrm{O}_{7}\right)$, the combination of phosphate and pyrophosphate groups enables the reversible $\mathrm{Na}$ ion (de-)insertion accompanied by the $\mathrm{Ni}^{2+/ 3+}$ redox activity. The $\mathrm{Na}_{4} \mathrm{Ni}_{3}\left(\mathrm{PO}_{4}\right)_{2}\left(\mathrm{P}_{2} \mathrm{O}_{7}\right)$ has been synthesized via a conventional solid-state method. The carbon coating process and the implementation of an ionic liquid-based electrolyte enables the reversible (de-)insertion of $1.3 \mathrm{Na}$ equivalents at an operating potential as high as $4.8 \mathrm{~V} \mathrm{vs} \mathrm{Na}^{+} / \mathrm{Na}$. Certainly, we are aware of the improvable electrochemical performance of the material; however, this is not the main objective of the present work. Meanwhile, searching for high voltage cathode materials opens a new and exciting perspective in the search for optimized and improved electrolyte solutions with a wider 
electrochemical stability window. Nevertheless, we believe that this study holds promise for obtaining cathode materials of a high working potential. The mixed polyanionic structure, combining phosphate and pyrophosphate frameworks, allows, thanks to the $\mathrm{P}_{2} \mathrm{O}_{7}$ dimers, the construction of large $\mathrm{Na}$ diffusion channels and, in consequence, small volume changes during cycling, representing a step towards overcoming the drawbacks of $\mathrm{Ni}$ analogs with low ionic/electronic conductivity and poor structural stability. The work presented herein shows, for the first time, the realization of Ni-based mixed polyanionic compounds and paves the way for the discovery of new Na-based high potential cathode materials.

\section{CONFLICT OF INTEREST}

The authors declare no conflict of interest.

\section{ACKNOWLEDGEMENTS}

$\mathrm{HZ}$ and BQ gratefully acknowledge the financial support from the Chinese State Scholarship Fund.

1 Tarascon, J. M. \& Armand, M. Issues and challenges facing rechargeable lithium batteries. Nature 414, 359-367 (2001).

2 Scrosati, B. \& Garche, J. Lithium batteries: status, prospects and future. J. Power Sources 195, 2419-2430 (2010).

3 Tarascon, J. M. Is lithium the new gold? Nat. Chem. 2, 510-510 (2010).

4 Slater, M. D., Kim, D., Lee, E. \& Johnson, C. S. Sodium-Ion Batteries. Adv. Funct. Mater. 23, 947-958 (2013)

5 Fisher, C. A. J., Hart Prieto, V. M. \& Islam, M. S. Lithium battery materials LiMPO $(\mathrm{M}=\mathrm{Mn}, \mathrm{Fe}, \mathrm{Co}$, and $\mathrm{Ni})$ : insights into defect association, transport mechanisms, and doping behavior. Chem. Mater. 20, 5907-5915 (2008).

6 Padhi, A. K., Nanjundaswamy, K. S. \& Goodenough, J. B. Phospho-olivines as positiveelectrode materials for rechargeable lithium batteries. J. Electrochem. Soc. 144, 1188-1194 (1997).

7 Wang, H., Yang, Y., Liang, Y., Cui, L.-F., Sanchez Casalongue, H., Li, Y., Hong, G., Cui, Y. \& Dai, H. LiMn ${ }_{1-x} \mathrm{Fe}_{x} \mathrm{PO}_{4}$ nanorods grown on graphene sheets for ultrahigh-rateperformance lithium ion batteries. Angew. Chem. 123, 7502-7506 (2011).

8 Ong, S. P., Chevrier, V. L., Hautier, G., Jain, A., Moore, C., Kim, S., Ma, X. \& Ceder, G. Voltage, stability and diffusion barrier differences between sodium-ion and lithium-ion intercalation materials. Energy Environ. Sci. 4, 3680-3688 (2011).

9 Feng, Y., Zhang, H., Fang, L., Ouyang, Y. \& Wang, Y. Designed synthesis of a unique single-crystal Fe-doped $\mathrm{LiNiPO}_{4}$ nanomesh as an enhanced cathode for lithium ion batteries. J. Mater. Chem. A 3, 15969-15976 (2015).

10 Bramnik, N. N., Nikolowski, K., Trots, D. M. \& Ehrenberg, H. Thermal stability of $\mathrm{LiCoPO}_{4}$ cathodes. Electrochem. Solid State Lett. 11, A89-A93 (2008).

11 Kim, S.-W., Kim, J., Gwon, H. \& Kang, K. Phase stability study of $\mathrm{Li}_{1-x} \mathrm{MnPO}_{4}$ $(0 \leqslant x \leqslant 1)$ cathode for $\mathrm{Li}$ rechargeable battery. J. Electrochem. Soc. 156, A635-A638 (2009).

12 Sanz, F., Parada, C., Rojo, J. M. \& Ruíz-Valero, C. Synthesis, structural characterization, magnetic properties, and ionic conductivity of $\mathrm{Na}_{4} \mathrm{M}_{3}{ }_{3}\left(\mathrm{PO}_{4}\right)_{2}\left(\mathrm{P}_{2} \mathrm{O}_{7}\right)\left(\mathrm{M}^{\prime \prime}=\mathrm{Mn}, \mathrm{Co}, \mathrm{Ni}\right)$. Chem. Mater. 13, 1334-1340 (2001).

13 Oh, S.-M., Myung, S.-T., Hassoun, J., Scrosati, B. \& Sun, Y.-K. Reversible $\mathrm{NaFePO}_{4}$ electrode for sodium secondary batteries. Electrochem. Commun. 22, 149-152 (2012).

14 Tripathi, R., Wood, S. M., Islam, M. S. \& Nazar, L. F. Na-ion mobility in layered $\mathrm{Na}_{2} \mathrm{FePO} 4 \mathrm{~F}$ and olivine $\mathrm{Na}[\mathrm{Fe}, \mathrm{Mn}] \mathrm{PO}_{4}$. Energy Environ. Sci. 6, 2257-2264 (2013).

15 Kim, H., Shakoor, R. A., Park, C., Lim, S. Y., Kim, J.-S., Jo, Y. N., Cho, W., Miyasaka, K., Kahraman, R., Jung, Y. \& Choi, J. W. $\mathrm{Na}_{2} \mathrm{FeP}_{2} \mathrm{O}_{7}$ as a promising iron-based pyrophosphate cathode for sodium rechargeable batteries: a combined experimental and theoretical study. Adv. Funct. Mater. 23, 1147-1155 (2013).

16 Barpanda, P., Ye, T., Avdeev, M., Chung, S.-C. \& Yamada, A. A new polymorph of $\mathrm{Na}_{2} \mathrm{MnP}_{2} \mathrm{O}_{7}$ as a $3.6 \mathrm{~V}$ cathode material for sodium-ion batteries. J. Mater. Chem. A 1, 4194-4197 (2013)

17 Saravanan, K., Mason, C. W., Rudola, A., Wong, K. H. \& Balaya, P. The first report on excellent cycling stability and superior rate capability of $\mathrm{Na}_{3} \mathrm{~V}_{2}\left(\mathrm{PO}_{4}\right)_{3}$ for sodium ion batteries. Adv. Energy Mater. 3, 444-450 (2013).

18 Sharma, N., Serras, P., Palomares, V., Brand, H. E. A., Alonso, J., Kubiak, P., Fdez-Gubieda, M. L. \& Rojo, T. Sodium distribution and reaction mechanisms of a $\mathrm{Na}_{3} \mathrm{~V}_{2} \mathrm{O}_{2}\left(\mathrm{PO}_{4}\right)_{2} \mathrm{~F}$ electrode during use in a sodium-ion battery. Chem. Mater. 26, 3391-3402 (2014)

19 Yabuuchi, N., Kubota, K., Dahbi, M. \& Komaba, S. Research development on sodium-ion batteries. Chem. Rev. 114, 11636-11682 (2014).

20 Lee, K. T., Ramesh, T. N., Nan, F., Botton, G. \& Nazar, L. F. Topochemical synthesis of sodium metal phosphate olivines for sodium-ion batteries. Chem. Mater. 23, 3593-3600 (2011).
21 Avdeev, M., Mohamed, Z., Ling, C. D., Lu, J., Tamaru, M., Yamada, A. \& Barpanda, P. Magnetic structures of $\mathrm{NaFePO}_{4}$ maricite and triphylite polymorphs for sodium-ion batteries. Inorg. Chem. 52, 8685-8693 (2013).

22 Kim, H., Park, I., Seo, D.-H., Lee, S., Kim, S.-W., Kwon, W. J., Park, Y.-U., Kim, C. S., Jeon, S. \& Kang, K. Understanding the electrochemical mechanism of the new iron-based mixed-phosphate $\mathrm{Na}_{4} \mathrm{Fe}_{3}\left(\mathrm{PO}_{4}\right)_{2}\left(\mathrm{P}_{2} \mathrm{O}_{7}\right)$ in a Na rechargeable battery. Chem. Mater. 25, 3614-3622 (2013).

23 Kim, H., Park, I., Seo, D.-H., Lee, S., Kim, S.-W., Kwon, W. J., Park, Y.-U., Kim, C. S., Jeon, S. \& Kang, K. New iron-based mixed-polyanion cathodes for lithium and sodium rechargeable batteries: combined first principles calculations and experimental study. J. Am. Chem. Soc. 134, 10369-10372 (2012).

24 Barpanda, P., Liu, G., Ling, C. D., Tamaru, M., Avdeev, M., Chung, S.-C., Yamada, Y. \& Yamada, A. $\mathrm{Na}_{2} \mathrm{FeP}_{2} \mathrm{O}_{7}$ : a safe cathode for rechargeable sodium-ion batteries. Chem. Mater. 25, 3480-3487 (2013).

25 Hautier, G., Jain, A., Ong, S. P., Kang, B., Moore, C., Doe, R. \& Ceder, G. Phosphates as lithium-ion battery cathodes: an evaluation based on high-throughput ab initio calculations. Chem. Mater. 23, 3495-3508 (2011).

26 Herle, P. S., Ellis, B., Coombs, N. \& Nazar, L. F. Nano-network electronic conduction in iron and nickel olivine phosphates. Nat. Mater. 3, 147-152 (2004).

27 Nose, M., Nakayama, H., Nobuhara, K., Yamaguchi, H., Nakanishi, S. \& Iba, H. Na ${ }_{4} \mathrm{Co}_{3}$ $\left(\mathrm{PO}_{4}\right)_{2} \mathrm{P}_{2} \mathrm{O}_{7}$ : a novel storage material for sodium-ion batteries. J. Power Sources 234, 175-179 (2013).

28 Wood, S. M., Eames, C., Kendrick, E. \& Islam, M. S. Sodium ion diffusion and voltage trends in phosphates $\mathrm{Na}_{4} \mathrm{M}_{3}\left(\mathrm{PO}_{4}\right)_{2} \mathrm{P}_{2} \mathrm{O}_{7}(\mathrm{M}=\mathrm{Fe}, \mathrm{Mn}, \mathrm{Co}$, Ni) for possible high-rate cathodes. J. Phys. Chem. C 119, 15935-15941 (2015).

29 Sanz, F., Parada, C., Amador, U., Monge, M. A. \& Valero, C. R. $\mathrm{Na}_{4} \mathrm{Co}_{3}\left(\mathrm{PO}_{4}\right)_{2} \mathrm{P}_{2} \mathrm{O}_{7}$, a new sodium cobalt phosphate containing a three-dimensional system of large intersecting tunnels. J. Solid State Chem. 123, 129-139 (1996).

30 Recham, N., Chotard, J. N., Dupont, L., Delacourt, C., Walker, W., Armand, M. \& Tarascon, J. M. A $3.6 \mathrm{~V}$ lithium-based fluorosulphate insertion positive electrode for lithium-ion batteries. Nat. Mater. 9, 68-74 (2010).

31 Gong, Z. \& Yang, Y. Recent advances in the research of polyanion-type cathode materials for Li-ion batteries. Energy Environ. Sci. 4, 3223-3242 (2011).

32 Shin, J.-H., Henderson, W. A. \& Passerini, S. Ionic liquids to the rescue? Overcoming the ionic conductivity limitations of polymer electrolytes. Electrochem. Commun. 5, 1016-1020 (2003)

33 Zhou, Q., Henderson, W. A., Appetecchi, G. B., Montanino, M. \& Passerini, S. Physical and electrochemical properties of N-Alkyl-N-methylpyrrolidinium Bis(fluorosulfonyl) imide ionic liquids: PY13FSI and PY14FSI. J. Phys. Chem. B 112, 13577-13580 (2008).

34 Yamamoto, O., Ogumi, Z., Morita, M., Krause, L. J., Lamanna, W., Summerfield, J., Engle, M., Korba, G., Loch, R. \& Atanasoski, R. Corrosion of aluminum at high voltages in non-aqueous electrolytes containing perfluoroalkylsulfonyl imides; new lithium salts for lithium-ion cells. J. Power Sources 68, 320-325 (1997).

35 La Mantia, F., Huggins, R. A. \& Cui, Y. Oxidation processes on conducting carbon additives for lithium-ion batteries. J. Appl. Electrochem. 43, 1-7 (2013).

36 Guerfi, A., Dontigny, M., Charest, P., Petitclerc, M., Lagacé, M., Vijh, A. \& Zaghib, K. Improved electrolytes for Li-ion batteries: mixtures of ionic liquid and organic electrolyte with enhanced safety and electrochemical performance. J. Power Sources 195, 845-852 (2010).

37 Guerfi, A., Duchesne, S., Kobayashi, Y., Vijh, A. \& Zaghib, K. LiFePO 4 and graphite electrodes with ionic liquids based on bis(fluorosulfonyl)imide (FSI) - for Li-ion batteries. J. Power Sources 175, 866-873 (2008).

38 Kundu, D., Tripathi, R., Popov, G., Makahnouk, W. R. M. \& Nazar, L. F. Synthesis, structure, and $\mathrm{Na}$-ion migration in $\mathrm{Na}_{4} \mathrm{NiP}_{2} \mathrm{O}_{7} \mathrm{~F}_{2}$ : a prospective high voltage positive electrode material for the $\mathrm{Na}$-ion battery. Chem. Mater. 27, 885-891 (2015).

39 Jarry, A., Gottis, S., Yu, Y.-S., Roque-Rosell, J., Kim, C., Cabana, J., Kerr, J. \& Kostecki, R. The formation mechanism of fluorescent metal complexes at the $\mathrm{Li}_{x} \mathrm{Ni}_{0.5} \mathrm{Mn}_{1.5} \mathrm{O}_{4-\delta} /$ carbonate ester electrolyte interface. J. Am. Chem. Soc. 137, 3533-3539 (2015).

40 Kim, J.-H., Pieczonka, N. P. W., Lu, P., Liu, Z., Qiao, R., Yang, W., Tessema, M. M., Sun, Y.-K. \& Powell, B. R. In situ formation of a cathode-electrolyte interface with enhanced stability by titanium substitution for high voltage spinel lithium-ion batteries. Adv. Mater. Interfaces 2, 1500109 (2015).

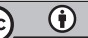

This work is licensed under a Creative Commons Attribution 4.0 International License. The images or other third party material in this article are included in the article's Creative Commons license, unless indicated otherwise in the credit line; if the material is not included under the Creative Commons license, users will need to obtain permission from the license holder to reproduce the material. To view a copy of this license, visit http:// creativecommons.org/licenses/by/4.0/

(C) The Author(s) 2017

Supplementary Information accompanies the paper on the NPG Asia Materials website (http://www.nature.com/am) 